\title{
The Development of Competitive Strategy for Prospective Export Commodities in Jambi
}

\section{M.Syurya Hidayat ${ }^{1}$, Muhammad Safri ${ }^{2}$}

${ }^{1}$ Faculty of Economic, University of Jambi, Jambi and Indonesia,

$\bowtie$ (e-mail) msyuryahidayat@unja.ac.id

${ }^{2}$ Faculty of Economic, University of Jambi, Jambi and Indonesia,

$\bowtie$ (e-mail) E-mail msyafri@unja.ac.id

\begin{abstract}
The development policies on Export commodity must be systematic and comprehensive. Hence, it is necessary to have an analysis of the competitive Export commodities affecting factors of development including development models and strategies. Therefore, this research was designed to be a quantitative descriptive research, collaborated with survey method. The analytical models; Time Series Analysis Model, The Indexes of Production and Stability Model Revealed Comparative Advantage (RCA) were used to identify the competitive Export commodities. Simultaneous Equation Analysis Model was used to identify the affecting factors on competitive export commodities development. Ex Post Historical Simulation and Ex-Ante Forecast Model were conducted to identify the commodity development prospect. In conclusion, the analysis results presented that firstly, the two competitive export commodities are $\mathrm{CPO}$ and rubber. Second, in terms of supply, the labor productivity, investment level, managerial capability and production technique as internal factor and raw material support, availability of land transportation infrastructure, bank credit, partnership with exporter, support of electric energy and seaport as external factor are the affecting factor from supply side. Whereas in terms of demand, the export commodity price factor, the export commodity price of the competitor, the exchange rate, the national income of the export destination country and the level of investment are the affecting factors that positively affect the demand side. Third, $\mathrm{CPO}$ and rubber are the prospective commodities to be developed as a competitive export commodity of Jambi Province.
\end{abstract}

Keywords: export, commodities, competitiveness

\section{Introduction}

One of the strategic policies in the economic sector development is through the industrial development strategy to produce the export-oriented commodities. This strategy, however, often ignores endowment factors which led to deficient export activities, industrial activities and other deficient related activities in an economic system. Accordingly, the concept of Agricultural DemandLed Industrialization by Adelman (Susilowati, 2008) becomes an important alternative.

The development policies on Export commodity supposed to be systematic and well-planned. The main focus of the strategy should be on eliminating the problems of export commodity development encountered so far, whether related to production problems, raw material supply, technological mastery, labor skills, capital land marketing aspects (Ženka at al.,2015). This means, the formulation of export commodity development strategy must be done comprehensively. The initial strategy in context of developing export commodity is through the development of competitive commodities (Granabetter, 2016).

In order to identify the competitive export commodities in the effort of export development, the commodity must meet several criteria. The first criterion should have a larger contribution than other 
commodities and show a positive development trend towards the total value of industrial export. Secondly, the commodity of the industry must have a level of stability in its production level. Thirdly, the commodity must also have a level of comparative advantage compared to other export commodities. The competitive export commodities are expected to provide any policy inputs in economic development and increased employments well as labor income by the industry (Aslam, at al.2016).

The initial analysis conducted through the re-identification of export commodities in which characterized by global competitiveness. Having identified the global-competitive export commodities, this research then analyzed the affecting factors on the development models (Decreux and Spies, 2016). Furthermore, this research analyzed the development prospect in accordance with the actual conditions to be organized in terms of its strategic development.

\section{Methods}

This research used descriptive quantitative method collaborated with survey method. Quantitative descriptive research method is used to identify the competitive commodities and the affecting factors on its development. In addition, survey is used to gain the data which represent the export development by taking samples. Sampling method used is Cluster Random Sampling Method. The number of selected sample is 50 export entrepreneurs.

In order to determine the competitive export commodities, which meet the predefined criteria, three models of analysis are used; Time Series Analysis model; Analysis Model of The Indexes of Production Instability (Bonjean and Motel, 2016) and Model Revealed Comparative Advantage (RCA). The expected end result of this first group of analysis models is the identification of 2 competitive export commodities.

The next model of analysis used is the Simultaneous Analysis Model within demand-supply approach. Mathematically, in terms of supply, the internal and external variables that influence the development of export commodities formulated as follow:

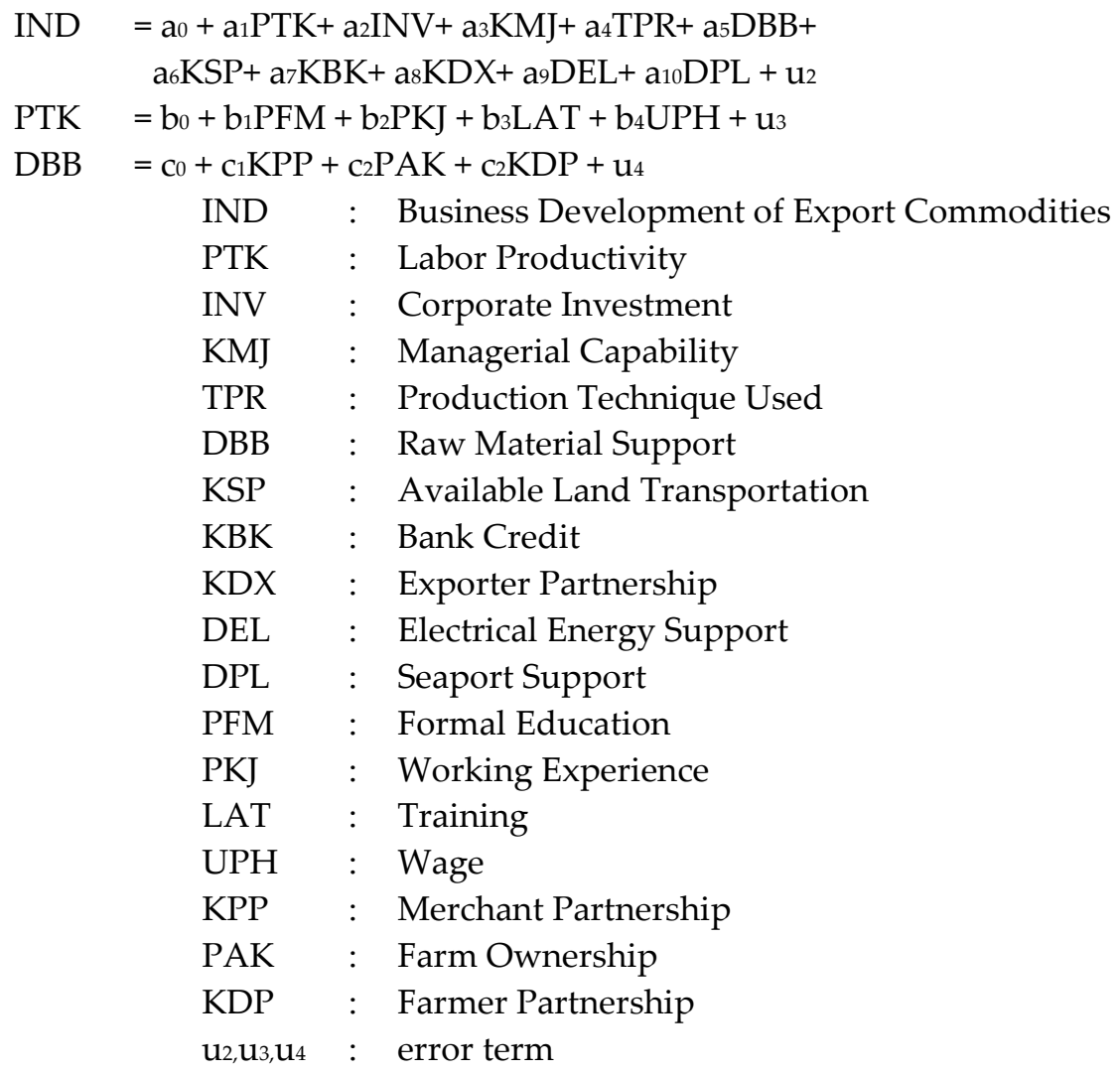


a,b,c : Regression Coefficient

In terms of demand, the affecting factors on competitive export commodities formulated as follow:

\begin{tabular}{|c|c|c|}
\hline \multicolumn{3}{|c|}{$\mathrm{HXA}_{t}=\mathrm{e}_{0}+\mathrm{e}_{1} \mathrm{PAU}_{\mathrm{t}}+\mathrm{e}_{2} \mathrm{KRP}_{\mathrm{t}}+\mathrm{e}_{3} \mathrm{PXA}_{\mathrm{t}}+\mathrm{e}_{4} \mathrm{VOL}_{t}+\mathrm{u}$} \\
\hline HXA & : & Export Commodity Value \\
\hline VOL & : & Volume of Competitive Export Commodities \\
\hline HXA & : & Export Commodity Value \\
\hline HXP & : & Export Commodity Value of Competitors \\
\hline KRP & : & Exchange Rate (IDR - USD) \\
\hline PTX & $:$ & National Income of Destination Country \\
\hline IIA & $:$ & Industrial Investment \\
\hline PAU & : & Total Production \\
\hline PXA & : & Demand of Competitive Export Commodities \\
\hline $\mathrm{t}$ & : & Time/ Year \\
\hline $\mathrm{u}_{5}, \mathrm{u}_{6}$ & & error term \\
\hline d,e & & Regression Coefficient \\
\hline
\end{tabular}

The projection analysis is done by using historical simulation analysis (ex-post) and forecasting simulation analysis (ex-ante). The historical simulation analysis used data period 2006-2016. The forecasting simulation analysis used data period 2017 - 2024. Several policy alternatives and simulation changes of some external factors are used for the purpose of the analysis.

\section{Results}

Three stages of analysis have been developed to identify the competitive export commodities. The first stage identifying each export commodity, which has the greatest contribution value and positive trend in its development to total export value of Jambi Province. The initial prerequisite that must be met in the identification of export commodities for the purposes of time series analysis is the continuity of export data from the analyzed commodities. Consequently, the analyzed commodities must be continuously exported every year and recorded at the Central Bureau of Statistics (BPS) of Jambi Province through Department of Industry and Trade (Deperindag) of Jambi Province.

Table 1 Average Contribution of Commodities towards Total Export - Time Series Analysis Results

\begin{tabular}{|c|c|c|}
\hline $\begin{array}{l}\text { Agro-industry } \\
\text { Commodities }\end{array}$ & $\begin{array}{l}\text { Average Contribution } \\
\text { towards Total } \operatorname{Exp}(\%)\end{array}$ & Time Series Analysis Results \\
\hline 1. $\mathrm{CPO}^{a}$ & 25.19 & $\mathrm{~V}_{1}=0.1990+0.0096 \mathrm{t}$ \\
\hline 2. Wooda & 8.52 & $\mathrm{~V}_{2}=0.0841+0.0002 \mathrm{t}$ \\
\hline 3. Rubber ${ }^{a}$ & 18.61 & $\mathrm{~V}_{3}=0.1590+0.0030 \mathrm{t}$ \\
\hline 4. Coffee & 0.08 & $\mathrm{~V}_{4}=0.0009-0.00001 \mathrm{t}$ \\
\hline 5. Shrimp & 0.58 & $\mathrm{~V}_{5}=0.0005+0.0010 \mathrm{t}$ \\
\hline 6. Fish & 0.13 & $\mathrm{~V}_{6}=-0.0003+0.0003 \mathrm{t}$ \\
\hline 7. Processed Food & 0.15 & $\mathrm{~V}_{7}=-0.00002+0.0003 \mathrm{t}$ \\
\hline 8. Pulpa & 12.65 & $\mathrm{~V}_{8}=-0.0247+0.0275 \mathrm{t}$ \\
\hline
\end{tabular}

Source:BPS (Central Bureau of Statistics) of Jambi Province, 2007-2017 (Processed Data)

NB : a $=$ Selected Export Commodities by Stage 1

Based on data presentation in Table 1 above, there are four commodities with average value of contribution to total export value exceeding $2.22 \%$ per year. The commodities are; CPO $(25.19 \%)$, Rubber (18.61\%), Paper / Pulp (12.65\%) and Wood (8.52\%). The four export commodities are the leading commodities of Jambi Province.

Based on the results of analysis in the first stage, further analysis is done by identifying the level of production stability. The identification of the production stability level of export commodities is done 
by using Indexes of Production Instability for each commodity. Table 2 presents the result of stability index for the top 4 contributors of export commodities in the first stage as follow:

Table 2 Analysis Result of Production Instability Index

\begin{tabular}{|lc|}
\hline Agro-industry Commodities & Index of Instability \\
\hline 1. $^{\mathrm{CPO}}$ Wood $^{\mathrm{b}}$ & 0.9778 \\
2. Woober & 0.1527 \\
3. Rubber & 0.6706 \\
4. Paper/Pulp & 16.3750 \\
\hline
\end{tabular}

Source:BPS (Central Bureau of Statistics) of Jambi Province, 2007-2017 (Processed Data)

NB $\quad: b=$ Selected Export Commodities by Stage 2

Table 2 presents the 3 commodities with a production stability index $<1$ (close to 0 ), which means that the commodity has a stability level in production, they are; CPO $(0.9778)$, Wood $(0,1527)$ and Rubber $(0,6706)$.

The analysis on export commodities through Revealed Comparative Advantage analysis model presented an RCA index for each of the selected export commodities in Stage 2. As presented in Table 3 , the results of the average RCA index analysis for the analysis data period of 2007-2017, as presented below:

Table 3 Analysis Result of Revealed Comparative Advantage

\begin{tabular}{|lll|}
\hline No & Agro-industry Products & RCA Index \\
\hline & & \\
1 & CPOc $^{c}$ & 9.0450 \\
2 & Wood & 0.7363 \\
3 & Rubber $^{c}$ & 6.7575 \\
\hline
\end{tabular}

Source: BPS (Central Bureau of Statistics) of Jambi Province, 2007-2017 (Processed Data)

NB $\quad: b=$ Selected Export Commodities by Stage 3

The analysis result of RCA on agro-industry commodities in Table 3 presented two commodities gain RCA index $>1$, they are; CPO $(9,0450)$ and rubber $(6,7575)$. In other words, both commodities have a comparative advantage compared to other competitive commodities of Jambi Province.

Heckscher Ohlin's theory of comparative advantage and proportion factor theory may explain the comparative advantage of the three commodities. Heckscher Ohlin's theory states that exports occurred due to the difference in opportunity costs between the two countries. The difference in costs is due to differences in endowment factors (labor, capital and raw materials) (Kogon, 2015).. This factor is actually what makes these three factors are superior especially when associated with raw materials and labor. Things to remember is that the advantages of both factors tend to be temporary. In a sense, along with technological progress it will shift the position of commodity advantage (Ottati,2018).

The analysis of internal and external affecting factors on commodity development, in terms of supply, indicated that over all, the test variables on internal factors and external factors statistically present a significant influence on the development of identified export commodities. This is indicated by the value of $F c t=27.698$ and $\rho=0.0001$ as every variation of industry development as dependent variable can be explained by variation of variables changes from internal and external factor as independent variable equal to $68,5 \%$. This is indicated by the adjusted value of $\mathrm{R}^{2}=0.685$.

Further identification of the effect of each variable of internal factors and external factors on the development of competitive commodities is done through partial test. Internal factor analysis based on test result shows that labor productivity (tct $=1,703 \rho=0,096)$, investment level (tct $=1,714 \rho=$ $0,094)$, managerial capability ( $\mathrm{tct}=1,936 \rho=0,060)$, and production technique (tct $=3,241$ production $=$ 0.002) provide a real effect on $\rho=0.01$. This means that the efforts to increase labor productivity through formal education, training and wage rates would have a positive impact on the development 
of competitive commodities similarly to industrial investment, managerial capability and improvement on production techniques.

In addition, the following external factors provided a significant effect on the development of competitive export commodities; raw material support (tct $=2.042 \rho=0,048$ ), availability of facilities and infrastructure $(\mathrm{t}$ account $=3,153 \rho=0,003)$, banking credit $(\mathrm{tct}=2,419 \rho=0,020)$, partnership with exporter (tct $=3,777 \rho=0,001)$ the availability of electrical energy ( $\mathrm{t}$ account $=2.853 \rho=0.007$ ) and seaport support $(\mathrm{t}=3.091=0.004)$.

Tabari and Reza (2012) assumed that the test results regarding the effect of labor productivity as an internal factor towards the development of agro-industry need to be clearly viewed. In that sense, these influences are in different levels of productivity. This is due to different capabilities in adopting production techniques by the labors which in further affect the optimal production capacity.

Provincial Government should pay more attention on facilities and transportation factors. These factors will affect the development of competitive export commodities in gaining input and transport costs. This in turn has an impact on production levels and product values. Moreover, Damuri (2012) expected that those factors would affect the commodity development in improving its competitiveness. Comprehensively, Table 4 presents the estimation result for internal-external factors on competitive commodity development.

Table 4 Estimation Result on Internal-External Factors towards Competitive Commodity Development; Supply Side

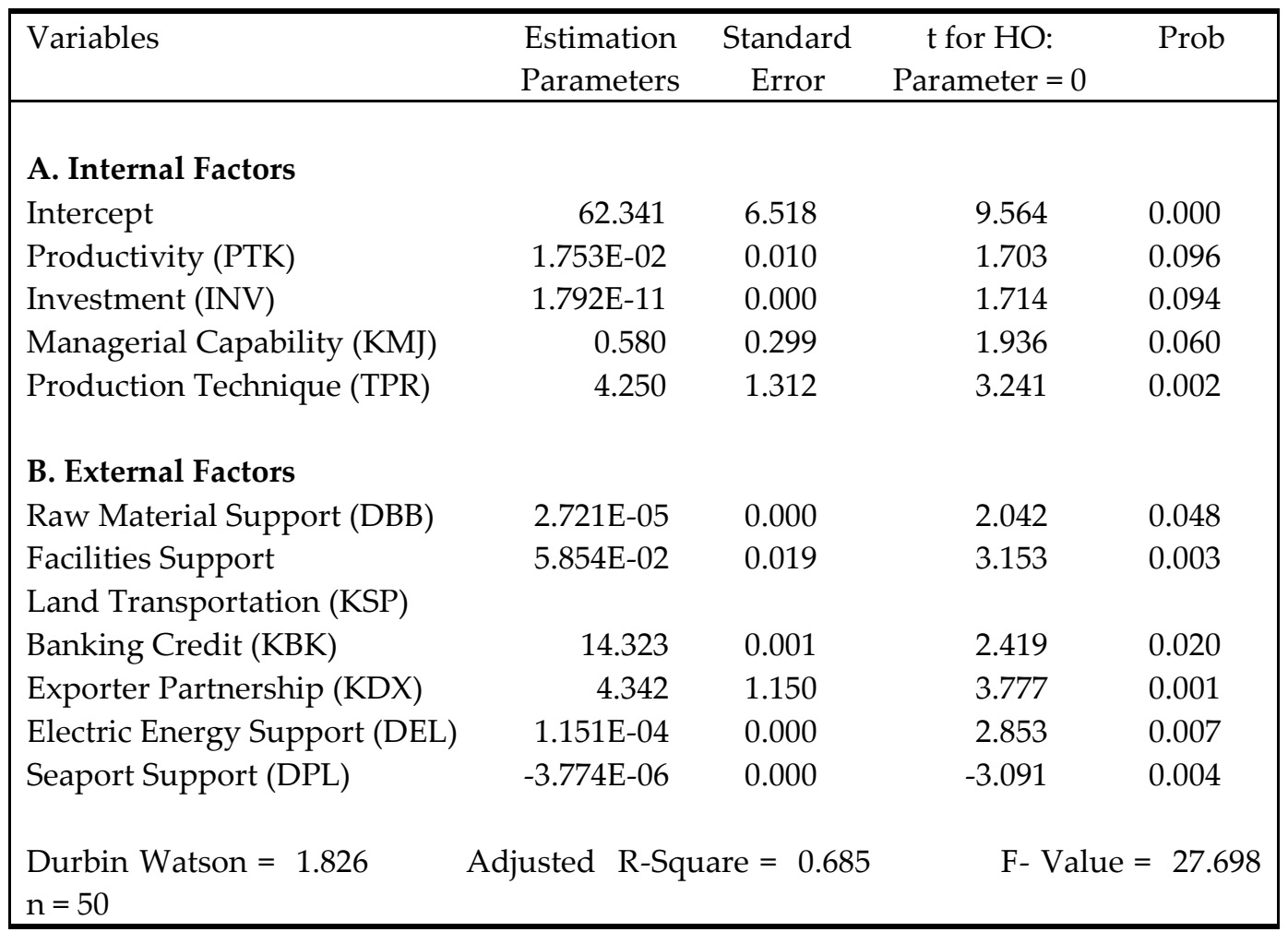

Source : Analysis Data

Statistically, the overall test result on competitive export commodity indicates that the following factors; commodity price, competitor commodity price, exchange rate value, national income of destination country and level of investment all have significant influence to CPO industry development. This is indicated by the value of $F c t=60.992$ and $\rho=0.0001$. The test results also show that the adjusted value of $\mathrm{R}^{2}=0.9585$. This means that every variation of export volume change as dependent variable can be explained by variation of change of independent variable equal to $95,85 \%$. 
Further analysis in identifying the influence of each variable is done through partial test. The test result show that commodity price (tct $=2,713 \rho=0,0265$ ), competitor's commodity price (tct $=-2,022 \rho$ $=0,0779)$, exchange rate ( $t c t=2.594 \rho=0,0319)$ investment $(t c t=2.481 \rho=0.0380)$ have significant effect on the development of export commodities. Meanwhile, the national income and export destination country (tct $=1,1,331 \rho=0,2199$ ) shows insignificant effect on the development of export commodities as presented in Table 5 .

Table 5 Estimation Result on Internal-External Factors towards Competitive Commodity Development; Demand Side

\begin{tabular}{|c|c|c|c|c|}
\hline Variables & $\begin{array}{l}\text { Estimation } \\
\text { Parameters }\end{array}$ & $\begin{array}{l}\text { Standard } \\
\text { Error }\end{array}$ & $\begin{array}{c}\mathrm{t} \text { for } \mathrm{HO}: \\
\text { Parameter }=0\end{array}$ & Prob \\
\hline Constant & -393631 & 167970 & $-2,343$ & 0,0472 \\
\hline $\begin{array}{l}\text { Commodity Price CPO } \\
\text { (HXA) }\end{array}$ & 624542 & 230223 & 2,713 & 0,0265 \\
\hline $\begin{array}{l}\text { Competitors Product Price } \\
\text { (HXPB) }\end{array}$ & -39839 & 19707 & $-2,022$ & 0,0779 \\
\hline Exchange Rate (KRP) & 31,454058 & 12,124671 & 2,594 & 0,0319 \\
\hline $\begin{array}{l}\text { National Income of } \\
\text { Destination Country (PTX) }\end{array}$ & $-23,198230$ & 17,431841 & $-1,331$ & 0,2199 \\
\hline Investment of CPO (IIA) & 0.304243 & 0,122607 & 2,481 & 0,0380 \\
\hline $\begin{array}{ll}\mathrm{D} W=1,896 \quad \text { Adjusted } \\
\mathrm{n}=20\end{array}$ & are $=0,9585$ & F- V & 60,992 & $=0,0001$ \\
\hline
\end{tabular}

Source :Analysis Data

The partial test results need to be understood in a more dynamic context when associated with the research conducted by Prasetyo and Darsono, (2017). According to Prasetyo and Darsono, the effect of exchange rate on export growth is only valid in the short term, but not so in the long term. In other words, in a long term, each variable may changed, then the accumulation of such changes may be negative. In addition, the overvalued exchange rates may also negatively influence the agro commodities (Bonilla and Reca, 2010). This means that the changes in exchange rate variables should be observable in the proper context and dimension to have correct anticipation.

On the other hand, simulation analysis is done to analyze the prospects for the development of export-oriented commodities. Forecasting simulations predicts the impacts when several policies and prospects for the development of competitive commodities. The analysis on the impacts is done by applying several scenarios that have been developed.

The forecasting simulation result is correlated to the development of competitive commodities which provide a prospective trend. This is indicated by the positive development of rubber export volume as a result of the policy instrument done as presented in Table 6.

Based on the forecasting simulation results, it can be concluded that the effect of combined scenarios of several policy instruments has the possibility of greater impact. Government and exporters need to have a well observation on this condition. As stated by Verter and Bečvařova (2016), the effectiveness of policies in the development of the export commodity development is strongly influenced by the ability in synergizing several policies. This is due to external environment encountered several conditions that can reduce the effectiveness of a policy and through a combination of policies, it can be minimized.

The forecasting simulation presents better prospects for competitive commodities; CPO. This is indicated by almost all simulated scenarios have a positive impact on CPO export volume. A large 
production has modest impact on the development of CPO. This of course needs to be observed and not taken as a priority policy. Aprina (2014) explained that the simulation results above can be understood as the policy changes in production level is commonly followed by opposing policies by other exporting countries. So the impact in the export market tends to be unchanged which means that the policy changes in production rates have low effectiveness.

Table 6 Forecasting Simulation Result of Competitive Commodity Development; Rubber

\begin{tabular}{|llc|}
\hline No & Scenarios & Export Volume Changes \\
\hline 1 & Investment Increased 20\% & 0.0546 \\
2 & Production Increased 10\% & -0.0002 \\
3 & Rubber Price Increased5\% & 0.0044 \\
4 & Exchange Rate Increased10\% & 0.1159 \\
5 & Export Demand Increased 10\% & 0.1019 \\
6 & Scenario Combination 1,2 & 0.0546 \\
7 & Scenario Combination1,2,4 & 0.2221 \\
8 & Scenario Combination1,4 & 0.2175 \\
\hline
\end{tabular}

Source: Analysis Data

Table 7 Forecasting Simulation Result on Export Commodity Development; CPO

\begin{tabular}{|llc|}
\hline No & Scenarios & Export Volume Changes \\
\hline 1 & Investment Increased 60\% & 0.2534 \\
2 & Production Increased 70\% & 0.0968 \\
3 & CPO Price Increased 2\% & 0.0029 \\
4 & Exchange Rate Increased10\% & 0.3363 \\
5 & Export Demand Increased 20\% & 0.0256 \\
6 & Scenario Combination1,2 & 0.2532 \\
7 & Investment Increased 30\%, Production & 0.5214 \\
& Increased 40\%, Exchange Rate Increased & \\
& 10\% & \\
8 & Investment Increased 30\%, Exchange Rate & 0.4644 \\
& Increased 10\% & \\
\hline
\end{tabular}

Source: Analysis Data

The exchange rate has a relatively high effectiveness towards CPO development. However, this policy instrument is well-considered not to be handled by the government as it would affect the economy in macro. According to Haronaand Ayojimib,(2015), what demanded from export commodity in relation to the exchange rate changes is the ability to predict and to prepare the anticipatory policies. If this has been able to be done then the exporter can compete in international trade (Nyatwongi, 2015).The forecasting simulation on CPO indicates that this export commodity has the prospect to grow and develop. This can be realized if the affecting factors by the supply side are also taken into account.

\section{Conclusions}

Having the analysis done, the researchers' concluded several pointers as follow:

1. $\mathrm{CPO}$ and rubber are the competitive agro-industry commodities in Jambi Province.

2. In terms of supply, the competitive export commodity significantly affected by the following internal factors; labor productivity, investment, managerial capability and production techniques and external factors; raw material support, availability of land transportation infrastructure, banking credit, partnership with exporters, electrical energy support and seaports.

3. In terms of demand, export commodity prices, competitors' commodity prices, exchange rates, national income of export destination countries and investment rates are several factors that have a positive influence on the development of competitive commodities. 
4. Two main export commodities; $\mathrm{CPO}$ and rubber have a prospect to be developed as the competitive commodity of Jambi Province if the government could pay more attention on the internal and external affecting factors as described above.

\section{Recommendations}

1. Provincial Government of Jambi need to pay more attention in the development of competitive export commodities especially in increasing the value added of products through industrialization process and increase the competitiveness of export commodities (competitive advantage). Therefore, it is essential to develop an area for competitive export commodities.

2. Substantial support from local government is required in an effort to increase the competitive advantage of the competitive export commodities, through banking institutions for investment, provision of infrastructure and facilities such as sea ports, land transportation, electric energy, market information, export promotion and labor training.

\section{Acknowledgment}

The researchers dedicate the deepest gratitude to all who have supported this research from the initial idea to refinement, the valuable inputs and review to make this research more comprehensible.

\section{References}

Aprina, H. (2014). The impact of crude palm oil price on rupiah's rate. Bulletin of Monetary, Economics and Banking, 16( 4)

Aslam,A.,Beidas-Strom,Samya.,Bems,R.,Celasun,v.,Çelik,SinemKılıç and Kóczán,Zsóka . (2016).Trading on Their Terms? Commodity Exporters in the Aftermath of the Commodity Boom. IMF Working Paper.

Bonjean, C. A and Motel, P. C. (2016).The economic consequences of export instability in developing countries: A Survey, Paper presented as an Annex to "On the Economic Vulnerability of Low Income Countries" by P.Guillaumont and prepared for the International Task Force on Commodity Risk Management in Developing Countries.

Decreux, Y and Spies, J. (2016). Export potential assessments : a methodology to identify export opportunities for developing countries, Seminars at ITC and WTO.

Granabetter, D.(2016). Revealed comparative advantageIndex: An analysis of export trade in the austrian district of burgenland, Review of Innovation And Competitiveness, 2(2)

Haron, R. A, Salami, M.( 2015).Malaysian crude palm oil market volatility: a GARCH approach. Int. Journal of Economics and Management 9 (S): 103 - 120

Maurice, K. (2015). Exporting Basics The Why's, How-To's and To-Do's for New Exporters, Kogon Printed,USA

Nyatwongi, L. N. (2015). Factors affecting the performance of importing and exporting small and medium enterprises in mombasa county. Kenya, School Of Business, University Of Nairobi

Ottati, G. D.(2018). Marshallian industrial districts in italy: the end of a model or adaptation to the global economy?,Cambridge Journal of Economics

Prasetyo, A.,Darsono, Sri, M. (2017). The influence of exchange rate on indonesian CPO export,Jurnal Ekonomi Pembangunan, 2(18)

Tabari, N.A. Y and Reza, Motiee. (2012). Technology and education effects on labor productivity in the agricultural sector in iran, European. Journal of Experimental Biology, 4(2)

Verter1, N and Bečvařova, V. (2016). The impact of agricultural exports on economic growth in nigeria, Acta Universitatis Agriculturaeet Silviculturae Mendelianae Brunensis, 64( 2)

Susilowati, S. H. (2008).Strategi agriculture demand led industrialization dalam perspektif peningkatan kinerja ekonomi dan pendapatan masyarakat, Jurnal Forum Penelitian Agro Ekonomi, $26(1)$ 
Ženka, j., Žufan, P.,Krtička, L.,Slach, O. (2015). Labour productivity of agricultural business companies and cooperatives in the Czech Republic: A micro-regional level analysis, Moravian Neographical Reports, 23(4) 